\title{
Examining consumer risk perceptions of prototypical brands versus me-too brands
}

\author{
Vanessa Quintal and Ian Phau
}

\begin{abstract}
This study examines brand familiarity, extrinsic attributes, self-confidence and perceived quality for their effects on perceived risk between prototypical and me-too brands. Factor analyses and path analysis were used in testing hypotheses. Brand familiarity produced a significant positive effect, while extrinsic attributes produced a significant negative effect on perceived equivalent quality for both the pioneer and me-too brands. Respectively, the perceived equivalent quality of the MP3 players produced significant positive and negative effects on perceived risks for pioneer and me-too brands. Managerial implications include strategic use of me-too brands and management of competitive advantages of pioneer brands with perceived prototypicality.
\end{abstract}

Keywords: prototypical brands, consumer risks, brand strategies, competitive advantage, me-too brands 


\section{INTRODUCTION}

Branding is the marketer's response to the risks consumers perceive in the marketplace (Laroche et al., 2004; Rubinstein, 1996). A pioneer brand is defined as the first entrant into a market (Robinson and Fornell, 1985) that creates a significantly new product category in the consumer's mind (Carpenter and Nakamoto, 1989; Liang, Cherian and $\mathrm{Fu}, 2010)$. Pioneer advantage or the competitive advantage accrued to the pioneer brand (Scherer, 1985; Kamins, 2003; Liang, Cherian and Fu, 2010; Sinapuelas and Robinson, 2012) results from several economic and psychological factors. First, the market learns more about pioneer brands since as the first entrant in the product category, they appear novel and attention-seeking. Second, pioneer brands are distinctive and unique, making awareness and recall easier. Third, pioneer brands generate a favorable image as they more closely match the consumer's self-image (Alpert and Kammins, 1995; Alpert et al., 2001; Carson, Jewell and Joiner, 2007; Lowe and Alpert, 2012). In 2002, Apple's launch of the Apple iPod created an entirely new market segment and propelled it to its pioneer brand status in the portable music market. It currently holds $70 \%$ of the market share, and Apple has sold over 350 million units since the iPod's introduction in 2002 (Travlos, 2012; Sloan, 2012).

Me-too brands represent challengers to the competitive advantage held by pioneer brands. The success of me-too brands may be attributed to their lower costs and higher quality through improved technology (Bohlmann et al., 2002; Hern et al., 2003; Carson, Jewell and Joiner, 2007; Sinapuelas and Robinson, 2012). Me-too brands are also not tied to tradition and monopolies, are innovative, pay attention to their customers and are not perceived to be arrogant and complacent. Prior to 2001, as the me-too brand and 
underdog competitor to software giant Microsoft, Apple revolutionized the market by offering a creative alternative to Microsoft's industry standards (Centaur Communications Limited, 2007a, 2007b).

Me-too brands are reported to have responded faster to the launch of a branded product, thus shortening the phase in which a unique concept can expect to reap premium prices and high margins (Centaur Communications Limited, 2007a, 2007b). While research has examined pioneer and me-too brands (e.g., Alpert and Kamins, 1995; Holt, 2002; Lowe and Alpert, 2012), there are gaps in explaining why some people intentionally avoid established brands (Kamins, 2003; Lee et al., 2009; Cromie and Ewing, 2009), while others continuously support me-too brands when risks about product quality, variety, price and even one's "face” (McGinnis and Gentry, 2009) abound.

The aim of the study is to examine several antecedentsrelated to consumer behavior for their differential effects on the dimensions of perceived risk between the pioneer (Apple iPod) and me-too brands (other brands of MP3 players) and to try to evaluate the relevance of these antecedents which help to explain this difference. As such, initiatives relating to the competitive advantage of pioneer prototypical brands versus metoo brands can be the blueprint of the design of the branding, advertising and product development strategies. 


\section{RELEVANT LITERATURE AND HYPOTHESES DEVELOPMENT}

The model for the current study was adapted and extended from research conducted by Mieres et al. (2006) by focusing on pioneer and me-too brands for their impact on perceived risk.

Perceived risk is defined as a subjective expectation of a potential loss occurring (Barkworth et al., 2002; Dholakia, 2001; Michaelidou and Christodoulides, 2011; Simcock et al., 2006; Sweeney et al., 1999). Some researchers suggest perceived risk arises from six different types of potential loss (e.g., Jacoby and Kaplan, 1972; Roselius, 1971; Forsythe et al., 2006; Javadi et al., 2012; Molina-Castillo, Lopez-Nicolas, and Soto-Acosta, 2012). Financial risk is a potential loss of money associated with the item purchase. Performance risk refers to a probable loss due to item failure after purchase (Eggert, 2006; Boksberger et al., 2007). Psychological risk reflects the possible loss of self-image or self-concept as the result of purchasing the item. Social risk is the potential loss of esteem, respect and/or friendship offered to the consumer by significant others due to the item purchase (Boksberger et al., 2007; Roehl and Fesenmaier, 1992). Physical risk refers to the potential loss of health or appearance as a result of using the item purchase (Forsythe et al., 2006). Time risk reflects a possible loss of time and effort associated with purchasing the item (Fuchs and Reichel, 2011; Murray and Schlacter, 1998). Each of these six dimensions of perceived risk is considered in the current study.

Brand familiarity reflects the 'share of mind' the consumer ascribes to a particular brand and the extent of a consumer's direct and indirect experience with the brand (Alba and Hutchinson, 1987; Kent and Allen, 1994; Ha and Perks, 2005; Delgado-Ballester et al, 2012). It is determined by strength of associations that the brand name evokes in 
consumer memory and in this way, captures the consumer's brand attitude (Campbell and Keller, 2003). It is likely that brand familiarity will positively influence perceptions of brand quality (Griffith and Gray, 2002; Low and Lamb, 2000; Petruzzellis et al., 2011) since consumers who are familiar with a brand tend to develop more favorable assessments of its quality. Therefore:

H1: As consumers become more familiar with the brands of MP3 players in the market, their perceptions of the equivalent quality of these brands will increase.

The degree of familiarity consumers have with a brand is expected to negatively impact on their perceived financial, performance, psychological, social, physical and time risks (de Chernatony, 1989; Richardson et al., 1996; Park and Stoel, 2005; Inci et al., 2011). It is possible that as consumers become more familiar with a brand, they are more comfortable with assessing it, which reduces the risk they perceive in the brand. Consequently:

H2: As consumers become more familiar with the brands of MP3 players on the market, their perceptions of risk associated with these brands will decrease.

An extrinsic cue is associated with the product; however an extrinsic cue can change without altering the characteristics of the product itself (Alonso, 2002). Generally, consumers rely upon the product's brand, physical appearance, purchase price (Dawar and Parker, 1994; Rao and Monroe, 1989) and country of origin (Fandos and Flavian, 2006; Kim, 2008) to determine its product quality. It is likely that reliance on a brand's extrinsic attributes will negatively influence the degree to which brand quality is perceived (Enneking et al., 2007; Espejel et al., 2007; Kumar and Grisaffe, 2004; Perrin- 
Martinenq, 2004). Consumers who become more certain about a brand's quality, depend less on its extrinsic attributes to purchase it. Therefore:

H3: As consumers rely more on the extrinsic attributes of the brands of MP3 players on the market, their perceptions of the equivalent quality of these brands will decrease.

When consumers hold little information about a brand's intrinsic attributes, their reliance on the brand's extrinsic attributes is expected to positively impact on the perceived financial, performance, psychological, social, and physical and time risks the brand poses (Griffith and Chen, 2004; Hsu and Lin, 2005; Aqueveque, 2006; Vieceli and Shaw, 2010). The more consumers rely on a brand's extrinsic attributes for reassurances about its ability to meet expectation, the more likely they are to perceive of the risks associated with the brand. Consequently:

H4: As consumers rely more on the extrinsic attributes of the brands of MP3 players on the market, their perceptions of risk associated with these brands will increase.

Self-confidence is considered a personality trait (Bearden and Teel, 1980; Tafarodi and Swann, 1996) that refers to the degree of self-assurance a consumer has in a specific marketing situation (Hellén and Sääksjärvi, 2011; Kamins et al., 2007; Locander and Hermann, 1979; Marc de Korte, 1977). It also reflects the level of self-belief the consumer possesses in protecting themselves from being misled in marketing exchanges (Gerbing et al, 1994). Consumers' self-confidence in a brand is likely to correlate positively with their perceptions of its quality (Rothman, 1980; de Chernatony and Riley, 1998; Ling, Shieh, and Liao, 2012.). It is possible that consumers who demonstrate more confidence in a brand will be more inclined to perceive its higher quality. Therefore: 
H5: As consumers become more confident about the brands of MP3 players on the market, their perceptions of the equivalent quality of these brands will increase.

Finally, perceived quality is an attitude that results from the comparison of consumer expectations with the actual performance (Parasuraman et al., 1985; Snoj et al., 2004). Consumers' perceptions about a brand's quality are expected to influence the risk they perceive in the brand. It is likely that perceived quality will negatively impact on the perceived risk a brand poses (Snoj et al., 2004; Sweeney et al., 1999). This is expected in situations when consumers perceive that the me-too brands on the market have similar high quality and therefore, associate less risk with these brands. However, since the metoo brands offer similar high quality on the market for a considerably lower price, purchasing a pioneer brand with its premium pricing may pose to be a bigger risk for the pioneer brand. Consequently:

H6a: As consumers become more acquainted with the equivalent quality of the MP3 players on the market, their perceptions of risk associated with the pioneer brand will increase.

H6b: As consumers become more acquainted with the equivalent quality of the MP3 players on the market, their perceptions of risk associated with the me-too brands will decrease.

\section{METHODOLOGY}

\section{Research design and sample}

Since lead users of MP3 players constitute young adults (Eggemann et al., 2002; Lenhart et al., 2010), the university student market was targeted. This is one of the most coveted 
consumer segments due to its market size, the role of university students as trendsetters, the lifelong brand loyalties acquired during these formative years, their position as earlyadopters, their influence over parental purchasers and the probability of a higher standard of living associated with an university degree (Noble et al., 2007; Wolburg and Pokrywezynski, 2001). A self-administered survey was used to collect the data through an intercept method in the campuses of three state universities in Australia. Every fifth individual who crossed a designated point at different locations of the campus was approached. Measuring consumers' attitudes and perceptions in a mall or shopping related environment would allow population of interest (in this case student users) to relate to what the research intends to measure, which in this case are attitudes and consumer purchase intention (Cowan, 1989). This is an improvement on ecological validity as most previous research focused on student samples (Wang et al., 2005).

\section{Measures}

The survey comprised four sections. The first two sections assessed the respondents' perceived risk in purchasing the pioneer and me-too brands respectively. Section three asked respondents about their brand familiarity, self-confidence, extrinsic attributes and perceived equivalent quality of the pioneer and me-too brands. Finally, respondents were asked to provide demographic information. Existing scales from Laroche et al. (2004) and Mieres et al. (2006) selected for their reliability in buying situations $(\alpha \geq 0.83)$ were anchored by strongly disagree (1) to strongly agree (7) and adapted to ensure relevance to the current study. 
Perceived risk for the Apple iPod (pioneer brand) and the other brands of MP3 players (me-too brands) were measured by 20 items respectively. Four statements each measured perceived social risk (e.g., I am afraid that an Apple iPod / another brand of MP3 player would negatively affect what others think of me) and perceived physical risk (e.g., I am afraid that an Apple iPod / another brand of MP3 player would not be safe for me or my family). Three statements each measured perceived financial risk (e.g., If I were to purchase an Apple iPod / another brand of MP3 player for myself within the next 12 months, I would be concerned that the financial investment I would make would not be wise), perceived performance risk (e.g., The thought of purchasing an Apple iPod / another brand of MP3 player causes me to be concerned for how really reliable that product will be), perceived psychological risk (e.g., The thought of purchasing an Apple iPod / another brand of MP3 player gives me an unwanted feeling of anxiety) and perceived time risk (e.g., Purchasing an Apple iPod / another brand of MP3 player could involve an inefficient use of my time).

Brand familiarity/experience with the MP3 players was measured by eight items (e.g., I am quite familiar with MP3 player brands other than the Apple iPod). Selfconfidence in choosing MP3 players was measured by five items (e.g., I consider myself capable of choosing a good MP3 player brand). Extrinsic attributes of MP3 players that determine quality was measured by seven items (e.g., the more expensive the MP3 player, the better the quality). Perceived quality between the MP3 players was measured by four items (e.g., There is not much difference in terms of quality between the Apple iPod brand and the other brands). Finally, seven questions related to gender, age, marital status, occupation, home ownership, education and income measured demographics. 


\section{RESULTS AND ANALYSIS}

Of the 362 surveys, 96 percent (348 surveys) administered were usable. This response rate was considered to be acceptable for a self-administered survey of this nature (Pinhey and Brown, 2005). Age and gender characteristics were representative of the general student population in Australia.

First, the 44 items related to risk perceptions of the Apple iPod (pioneer brand) were factor analyzed using a VARIMAX rotation to establish their structure and dimensionality. The initial analysis suggested a preliminary nine-factor solution which explained 65 percent of the total variance with a KMO score of 0.88 and a Bartlett's test of Sphericity of 0.001. Due to cross-loadings and communalities of less than 0.5 , the factor analysis was rerun iteratively. This resulted in 10 items being removed which identified factors that maintained independence from one another. As can be seen in Table 1, the final solution highlighted seven factors which maintained the total variance explained at 65 percent with a KMO score of 0.88 and a Bartlett's test of Sphericity of 0.001. The seven factors identified brand familiarity, extrinsic attributes, perceived quality, perceived social/physical risk, perceived financial/performance risk, perceived time risk and perceived psychological risk.

Then, the 44 items related to risk perceptions of the other brands of MP3 players (me-too brands) were factor analyzed. Again, the initial analysis suggested a preliminary nine-factor solution which explained 67 percent of the total variance with a KMO score of 0.88 and a Bartlett's test of Sphericity of 0.001 . When the factor analysis was rerun 
iteratively, 13 items were removed. As can be seen in Table 2, the final solution highlighted seven factors which improved the total variance explained to 69 percent with a KMO score of 0.86 and a Bartlett's test of Sphericity of 0.001 . The seven factors also identified brand familiarity, extrinsic attributes, perceived quality, perceived social/physical risk, perceived financial/performance risk, perceived time risk and perceived psychological risk.

Insert Table 1 here

$\sim$ Insert Table 2 here

Next, confirmatory factor analysis tested the measurement properties of each of the seven constructs related to the Apple iPod (pioneer brand) and the other brands of MP3 players (me-too brands) respectively. Items with high modification index values due to correlated error terms and low loadings were omitted (Jöreskog and Sörbom, 1993). As a result, 10 items were deleted from the measures related to the Apple iPod (pioneer brand), leaving 23 items, and four items were deleted from the measures related to the other brands of MP3 players (me-too brands), leaving 27 items.

As can be seen in Appendix 1, composite reliabilities for the Apple iPod (pioneer brand) and the other brands of MP3 players (me-too brands) were 0.85 and 0.91 for brand familiarity; 0.63 and 0.72 for extrinsic attributes; 0.61 for perceived quality; 0.89 and 0.92 for perceived social/physical risk; 0.85 and 0.81 for perceived financial/performance risk; 0.81 and 0.85 for perceived time risk and 0.88 and 0.92 for perceived psychological 
risk respectively, suggesting the constructs demonstrated some reliability (Hair et al., 2006).

The composite reliabilities and the average variance extracted (AVE) scores, as can be seen in Appendix 1, suggested that the various constructs had good measurement properties (reliability and convergent validity) for the Apple iPod (pioneer brand) and the other brands of MP3 players (me-too brands) (Fornell and Larcker, 1981). Further, an examination of the squared correlations between the various constructs found a maximum value of 0.45 (between perceived time risk and perceived psychological risk for the metoo brands), which was well below the AVE scores for both constructs (0.66 and 0.78$)$. Consequently, discriminant validity for the constructs could also be assumed in all cases (Fornell and Larcker, 1981).

As can be seen in Table 3, independent groups t-tests suggested differences in respondents' risk perceptions between the Apple iPod (pioneer brand) and the other brands of MP3 players (me-too brands). When it involved the me-too brands, respondents held significantly higher perceived social/physical risk $(\mathrm{p} \leq 0.01)$, perceived financial/performance risk $(\mathrm{p} \leq 0.001)$ and perceived psychological risk $(\mathrm{p} \leq 0.001)$ than the Apple iPod. However, perceived time risk $(\mathrm{p} \leq 0.05)$ was significantly higher for the Apple iPod than the me-too brands.

$\sim$ Insert Table 3 here

Finally, path analysis examined the model's hypotheses. As can be seen in Figure 1, the model for the Apple iPod (pioneer brand) fitted the data well (RMSEA $\leq 0.06$; NFI $\geq 0.92$; CFI $\geq 0.95$ and AGFI $\geq 0.96$ ). The model for the other brands of MP3 players 
(me-too brands) fitted the data reasonably well (although RMSEA $\leq 0.09$, the other indices of NFI $\geq 0.95 ; \mathrm{CFI} \geq 0.96$ and $\mathrm{AGFI} \geq 0.97$ were acceptable), as can be seen in Figure 2. Further, no modification indices suggested other paths between the models' constructs should be considered.

Since perceived risk and perceived quality are identified as formative constructs, items measuring the respective two constructs were summed to create composites, as suggested by Jarvis et al. (2003). The error for each formative construct was then set to 0.15 times the variance of the item, as suggested by Jöreskog and Sörbom (1993). Brand familiarity and extrinsic attributes are identified as reflective constructs with more than three items. The items for each reflective construct were combined using a partial disaggregation approach to minimize measurement error problems (Bagozzi and Heatherton, 1994). Partial disaggregation is accomplished by randomly aggregating items that relate to a given construct into two or three composite measures so all of the items related to the latent variable correspond in the same way to that latent variable; thus any combination of the items should yield the same model fit (Dabholkar et al., 1996).

As expected, brand familiarity produced a significant positive effect on the perceived equivalent quality of the MP3 players for both the Apple iPod (pioneer brand) $(b=0.24, p \leq 0.001)$ and the other brands of MP3 players (me-too brands) $(b=0.66, p \leq$ 0.001). This suggested respondents who were well versed with the brands of MP3 players available on the market also discerned that these brands had similar qualities, supporting H1. However, brand familiarity did not produce the hypothesized significant negative effect on any of the dimensions of perceived risk for both the Apple iPod (pioneer brand) and the other brands of MP3 players (me-too brands), which did not support H2. 


\section{$\sim$ Insert Figure 1 here}

Extrinsic attributes, as predicted, produced a significant negative effect on the perceived equivalent quality of the MP3 players for both the Apple iPod (pioneer brand) $(b=-0.29, p \leq 0.001)$ and the other brands of MP3 players (me-too brands) $(b=-0.61, p$ $\leq 0.001)$. This suggested respondents who placed importance on external cues such as a premium brand, packaging and pricing were less inclined to perceive that the MP3 players on the market shared similar qualities, supporting H3. However, extrinsic attributes did not produce the hypothesized significant positive effect on any of the dimensions of perceived risk for both the Apple iPod (pioneer brand) and the other brands of MP3 players (me-too brands), which did not support H4.

As hypothesized, the perceived equivalent quality of the MP3 players had significant positive effects on perceived social/physical $(\mathrm{b}=0.83, \mathrm{p} \leq 0.001)$, financial/performance $(b=0.59, p \leq 0.001)$, time $(b=0.76, p \leq 0.001)$ and psychological $(b=0.87, p \leq 0.001)$ risks for the Apple iPod (pioneer brand), supporting H6a. When it involved the Apple iPod, respondents appeared to perceive more risk about whether the pioneer brand would meet expectation and social approval for the time and money expended in purchasing it.

Also as expected, the perceived equivalent quality of the MP3 players had a significant negative effect on perceived financial/performance risk $(b=-0.31, p \leq 0.001)$ for the other brands of MP3 players (me-too brands), supporting H6b. With the number of me-too brands that offer equivalent quality on the market, respondents seemed to find more assurance and perceive less risk in purchasing these brands. No significant effects 
were observed for the other three dimensions of risk, although there was directional support from each of these risk dimensions.

Finally, since the self-confidence construct did not load as an independent and separate factor from the initial factor analysis, it was not included in the measurement model and H5 remained untested.

$\sim$ Insert Figure 2 here

\section{DISCUSSION AND CONCLUSION}

The primary aim of the current study was to examine the differential effects brand familiarity, extrinsic attributes and perceived quality had on perceived social/physical, financial/performance, time and psychological risks for the Apple iPod (pioneer brand) and the other brands of MP3 players (me-too brands). The constructs demonstrated reliability as well as convergent and discriminant validity and the majority of the hypotheses were supported as can be seen in the measurement models in Figures 1 and 2.

Me-too brands posed significantly higher social/physical, financial/performance and psychological risks for respondents. However, time risk was significantly higher for the pioneer brand. This augurs well for the Apple iPod as it suggests that in spite of the aggressive competition mounted by the me-too brands on the market, consumers are still able to discern the competitive advantage offered by the pioneer brand, although they are taking more time to decide on its purchase. 
As expected, brand familiarity produced a significant positive effect on the perceived equivalent quality of the MP3 players for both the Apple iPod and the other brands of MP3 players. This may present a future problem for the Apple iPod since savvy consumers who shop around and become familiar with the different MP3 players on the market appear to see no difference in the quality of the brands. Consumer familiarity with the me-too brands may be a reason why unit sales for the Apple iPod are expected to tumble by 12 percent to about 48 million in 2009 (Hesseldahl, 2008).

Extrinsic attributes, as predicted, produced a significant negative effect on the perceived equivalent quality of the MP3 players for both the Apple iPod and the other brands of MP3 players. This augurs well for the Apple iPod since consumers who place high importance on its premium brand, packaging and pricing are less inclined to perceive that all the MP3 players on the market share similar qualities.

Neither brand familiarity nor extrinsic attributes had any significant effect on the dimensions of perceived risk for the Apple iPod and the other brands of MP3 players. This suggests consumers do not draw upon their experience with the pioneer and me-too brands nor do they use the brands' tangible cues to help allay any risks associated with purchasing them. As reported in the previous paragraphs, it is likely that consumer perceptions of quality may hold stronger influence in helping them cope with purchase risks (Snoj et al., 2004; Sweeney et al., 1999).

As hypothesized, the perceived equivalent quality of the MP3 players produced significant positive effects on perceived social/physical, financial/performance, time and psychological risks for the Apple iPod. Consumers who perceive the equivalent quality of the MP3 players on the market appear to associate more risk with the Apple iPod. 
Possibly, since the pioneer brand costs more to purchase, consumers may be more concerned that it might not live up to expectation or meet the approval of significant others for the time and effort taken to purchase it. The Apple iPod may need to consider the implications of guarantees and extended warranties to allay such perceived risks.

Also as expected, the perceived equivalent quality of the MP3 players produced a significant negative effect on the perceived financial/performance risk for the other brands of MP3 players. Conceivably, consumers may perceive that the real quality in the me-too brands stems from the value-for-money they offer and the lower risk they pose. Since the key issues of cost and performance appear to be addressed by the equivalent quality of the me-too brands on the market, the other dimensions of risk may not be applicable to this savvy market segment.

\section{LIMITATIONS AND FUTURE RESEARCH}

The sample's size and geographic distribution limited generalizability of the findings. For the model to have general and cross-cultural applicability, it requires replication using different countries and cultures (Noble et al., 2009) to strengthen confidence in the results (Alpert et al., 2001). The product MP3 which is used in this study is at the end of its lifecycle. It does make sense to replicate this study with other products as smart phones and tablets which can be more appropriate with the current market.

From the research, it is apparent consumers hold the pioneer brand in high regard, acknowledging that the brand meets social approval and provides assurance in terms of its high standards of performance and safety for the price it commands. This augurs well 
for pioneer brands as it demonstrates they are able to maintain their competitive edge. However, consumers seem reluctant to take the time to accumulate information about the pioneer brand's attributes, particularly when the financial outlay required by the pioneer brand is high. It may be worthwhile to explore the time/money tradeoff that consumers encounter in such situations. Given their time-poor lifestyles, are consumers willing to sacrifice leisure time by searching for information to reduce their risks (Laroche et al., 2004) or not sacrifice leisure time by buying pioneer brands at premium prices for the assurances they give?

Consumer reliance on extrinsic cues to determine brand quality and manage perceived risk requires further investigation, specifically in the area of cross-cultural research. Many researchers consider that Asian consumers are more brand conscious, sensitive to extrinsic cues ( $\mathrm{Na}$ et al., 2007) and desirous of social approval from their collectivistic communities (Tafarodi and Swann, 1996). In Asian societies, it is likely the relationships between extrinsic cues, brand quality and perceived risk will be more pronounced than findings in the current study. Understanding how the suggested model works in China and Japan could help pioneer brands address perceptions of risk, quality and social acceptance and maintain their competitive edge in these large and culturallysensitive consumer markets.

In previous studies, females were found to be more risk-avoiding than their male counterparts (Levin et al., 1988; Verma and Sharma, 1990). Yet, it is possible that better education and improved social status may empower more women to be less susceptible to fear and anxiety and to perceive less risk (Carr, 2001). Further research is required to 
examine the impact gender has on the perceived risk associated with purchasing consumer electronics, which has traditionally been a male-dominated area.

Consumer retrieval of pioneer brands and identification of pioneer status are important issues for which additional sets of real product categories should be tested. A number of additional issues remain to be addressed in future research. For instance, what is it about 'The Original' that makes this term more powerful than other terms that communicate pioneer status (including 'The Pioneer')? Why do consumers misperceive pioneer status? What leads them to misidentify a particular brand as a pioneer? Will cross-cultural replication find differing degrees of enthusiasm for pioneer brands on the basis of differing core cultural values toward change (Alpert and Kamins, 1995)?

Finally, subsequent research could investigate why consumers reject specific pioneer and me-too brands. In some instances, the risk perceptions and motives may be intentional, where consumers make active choices. Active choices in rejecting brands may result from prior experience where a brand has neither met expectations nor shown compatibility with a consumer's image or morals. In other instances, the risk perceptions and motives may be intuitive, where consumers have no choice. Intuitive choices in rejecting brands may result from brands being expensive, unavailable and inaccessible (Lee et al., 2009). Understanding why and how consumers make these choices could provide fresh perspectives into issues of anti-consumption and brand avoidance.

\section{REFERENCES}


Alba J.W., Hutchinson J.W. (1987). Dimensions of consumer expertise. Journal of Consumer Research, 13, 411-453.

Alonso, Ma Aranzazu Sule, Paquin, Jean-paul, and Mangin, Jean-pierre Levy. (2002). Modelling perceived quality in fruit products: their extrinsic and intrinsic attributes. Journal of Food Products Marketing, 8, 29-48.

Alpert, Frank, and Kamins, Michael A. (1995). An empirical investigation of consumer memory, attitude and perceptions towards pioneer and follower brands. Journal of Marketing, 59,34-46.

Alpert, Frank, Kamins, Michael, Sakano, Tomoaki, Onzo, Naoto, and Graham, John. (2001). Retail buyer beliefs, attitude and behavior toward pioneer and me-too follower brands: a comparative study of Japan and the USA. International Marketing Review, 18, 160-187.

Aqueveque, Claudio. (2006). Extrinsic cues and perceived risk: the influence of consumption situation. Journal of Consumer Marketing, 23, 237-247.

Bagozzi, R., Dholakia, U., Basuroy, S. (2003). How effortful decisions get enacted: the motivating role of decision processes, desires, and anticipated emotions. Journal of Behavioral Decision Making, 16,273-295.

Bailey, B.C. (1999). The risk of store brand grocery products: effects of usage occasion and serving method on risk perception and brand choice. Doctoral dissertation. State University of New York, Buffalo, New York.

Barkworth, L., Hibbert, S., Horne, S., and Tagg, S. (2002). Giving at risk? Examining perceived risk and blood donation behavior. Journal of Marketing Management, 18, 905-922.

Boksberger, Philipp E., Bieger, Thomas, and Laesser, Christian. (2007). Multidimensional analysis of perceived risk in commercial air travel. Journal of Air Transport Management, 13, 90-96.

Bohlmann, J., Golder, P., and Mitra, D. (2002). Deconstructing the pioneer's advantage: examining vintage effects and consumer valuations of quality and variety. Management Science, 48 1175-1195.

Campbell, M.C., and Keller, K.L. (2003). Brand familiarity and advertising repetition effects. Journal of Consumer Research, 30,292-304.

Carpenter, G.S., and Nakamoto, K. (1989). Consumer preference formation and pioneer advantage. Journal of Marketing Research, 26, 258-298.

Carr, N. (2001). An exploratory study of gendered differences in young tourists perception of danger within London. Tourism Management, 22,565-570. 
Carson, S.J., Jewell, R.D., and Joiner, C. (2007). Prototypicality advantages for pioneers over me-too brands: the role of evolving product designs. Journal of the Academy of Marketing Science, 35, 172-183.

Centaur Communications Limited. Challenger Brands: rules for being a successful challenger brand. Brand Strategy 2007a:44 (9 October).

Centaur Communications Limited. (2007). Challenger Brands: are you up to the challenge? Brand Strategy, 44.

Cherry, J, and Fraedrich, J. (2002). Perceived risk, moral philosophy and marketing ethics: mediating influences on sales managers' ethical decision-making. Journal of Business Research, 55, 951-962.

Cromie, John G., and Ewing, Mike T. (2009). The rejection of brand hegemony. Journal of Business Research, 62, 218-230.

Cowan, C. D. 1989, "Mall Intercepts and Clinical Trials: The Philosophy of Inference From Different Types of Research Designs", Marketing Research, Vol.1, Iss. 1, pp. $15-22$.

Dabholkar, P., Thorpe, D., and Rentz, J. (1996). A measure of service quality for retail stores: Scale development and validation. Journal of the Academy of Marketing Science, 24, 3-16.

Dawar, N., Parker, P. (1994). Marketing universals: consumers' use of brand name, price, physical appearance, and retail reputation as signals of product quality. Journal of Marketing, 58, 81.

de Chernatony, L. (1989). Understanding consumers' perceptions of competitive tiers can perceived risk help? Journal of Marketing Management, 4, 288-299.

de Chernatony, L, and Riley, F. (1998). Defining a "brand": beyond the literature with experts' interpretations. Journal of Marketing Management, 14, 417-443.

Delgado-Ballester, E., Navarro, A., and Sicilia, M. Revitalising brands through communication messages: the role of brand familiarity. European Journal of Marketing, 46, 31-51.

Dholakia, U. (2001). A motivational process model of product involvement and consumer risk perception. European Journal of Marketing,35,1340-1360.

Eggemann, C., Koester, M., and Zorowka, P. (2002). Hörschäden durch Freizeitläm nehmen zu. Auch das Ohr braucht mal Pause. MMW Fortschr Med. 144:30-33.

Eggert, A. (2006). Intangibility and perceived risk in online environments. Journal of Marketing Management, 22, 553-572. 
Enneking, U., Neumann, C., and Henneberg, S. (2007). How important intrinsic and extrinsic product attributes affect purchase decision. Food Quality and Preference, $18,133-138$.

Fandos, C., Flavin, C. (2006). Intrinsic and extrinsic quality attributes, loyalty and buying intention: an analysis for a PDO product. British Food Journal, 108, 646-662.

Fornell, C., Larcker, D. (1981). Evaluating structural equation models with unobservable variables and measurement error. Journal of Marketing Research, 18, 39-50.

Forsythe, Sandra, Liu, Chuanlan, Shannon, David, and Gardner, Liu Chu. (2006). Development of a scale to measure the perceived benefits and risks of online shopping. Journal of Interactive Marketing, 20, 55-75.

Fuchs, G., and Reichel, A. (2011). An exploratory inquiry into destination risk perceptions and risk reduction strategies of first time vs. repeat visitors to a highly volatile destination. Tourism Management 2011; 32(2): 266-276.

Gerbing, D., Hamilton, J., and Freeman, E. (1994). A Large-scale second-order structural equation model of the influence of management participation on organizational planning benefits. Journal of Management, 20, 859-885.

Griffith, D., and Chen, Q. (2004). The influence of virtual direct experience (VDE) on on-line ad message effectiveness. Journal of Advertising, 33, 55-68.

Ha, Hong-Youl, and Perks, Helen. (2005). Effects of consumer perceptions of brand experience on the web: brand familiarity, satisfaction and brand trust. Journal of Consumer Behavior, 4, 438-452.

Hair, J., Anderson, R., Tatham. R., and Black, W. (2006). Multivariate Data Analysis. New Jersey: Prentice-Hall.

Hellén, K., and Sääksjärvi, M. (2011). Is consumer self-confidence a stable phenomenon? The effect of mood on self-confidence dimensions. Journal of Customer Behaviour, $10,223-243$.

Hern, L.E., de Chernatony, L., Iversen, N.M. (2003). Factors influencing successful brand extensions. Journal of Marketing Management, 19, 781-806.

Holt, D.B.(2002). Why do brands cause trouble? A dialectic theory of consumer culture and branding. Journal of Consumer Research, 29, 70-90.

Hsu, T., Lin, L. (2005). Using fuzzy set theoretic techniques to analyze travel risk: an empirical study. Tourism Management, 27, 968-981.

Inci, Dursun, Ebru T. K., Alev, K. A., and Bülent S. (2011). Store brand purchase intentions: effects of risk, quality, familiarity and store brand shelf space. ProcediaSocial and Behavioral Sciences, 24, 1190-1200. 
Jacoby, J., Kaplan, L. (1972). The components of perceived risk. Paper presented at the Third Annual Conference of the Association for Consumer Research, Chicago, IL.

Jarvis, C., Mackenzie, S., and Podsakoff, P. (2003). A critical review of construct indicators and measurement model misspecification in marketing and consumer research. Journal of Consumer Research, 30, 199-218.

Javadi, M. H., Dolatabadi, H. R., Noubakhsh M., Poursaeedi, A., and Asadollahi, A. R. (2012). An analysis of factors affecting on online shopping behavior of consumers. International Journal of Marketing Studies, 4, 81-98.

Jöreskog, K, and Sörbom, D. (1993). LISREL VII: Structural Equation Modeling With The SIMPLIS Command Language. Chicago: Scientific Software International.

Kamins, M., Alpert, F., and Perner. L. (2003). Consumers' perception and misperception of market leadership and market pioneership. Journal of Marketing Management, 19, 807-834.

Kamins, M., Alpert, F., and Perner, L. (2007). How do consumers know which brand is the market leader or market pioneer? Consumers' inferential processes, confidence and accuracy. Journal of Marketing Management, 23, 590-611.

Kent, R.J., and Allen, C.T. (1994). Competitive interference effects in consumer memory for advertising: the role of brand familiarity. Journal of Marketing, 58, 97-105.

Kim, R. (2008). Japanese consumers' use of extrinsic and intrinsic cues to mitigate risky food choices. International Journal of Consumer Studies, 32, 49-58.

Laroche, M., McDougall, G., Bergeron, J.Y. (2004). Exploring how intangibility affects perceived risk. Journal of Services Research, 6, 373-389.

Lee, Michael, Motion, Judith, and Conroy, Denise. (2009). Anti-consumption and brand avoidance. Journal of Business Research, 62, 169-180.

Lenhart, Amanda, Purcell, Kristen, Smith, Aaron, and Zickuhr, Kathryn. (2010). Social media \& mobile internet use among teens and young adults.

Levin, I., Synder, M., and Chapman, D. (1988). The interaction of experiential and situation factors and gender in a simulated risky decision-making task. Journal of Psychology, 122, 173-181.

Liang, Beichen, Cherian, Joseph \& Fu, Wei. (2010). Can followers overcome pioneers? The role of superior alignable differences in consumer evaluation of brand extensions. Journal of Product \& Brand Management 19, 813-821.

Ling, I-Ling, Shieh, Chih-Hui, and Liao, Jun-Fang. (2012). The higher the price, the better the result? The placebo-like effects of price and brand on consumer judgments. Theoretical Economic Letters, 2, 264-269. 
Locander, W., and Hermann, P. (1979). The effect of self-confidence and anxiety on information seeking in consumer risk reduction. Journal of Marketing Research, 16, 268-274.

Low, G., and Lamb, C. (2000). The measurement and dimensionality of brand associations. Journal of Product and Brand Management, 9, 350-370.

Lowe, Ben and Alpert, Frank. 2010. The relative influence of pioneer and follower price on reference price and value perceptions. Journal of Product \& Brand Management, 19, 504-511.

Marc de Korte, J. (1977). Mail and telephone shopping as a function of consumer selfconfidence. Journal of Academy of Marketing Science, 5, 295-306.

McGinnis, L.P., and Gentry, J.W. (2009). Underdog consumption: an exploration into meanings and motives. Journal of Business Research, 62, 191-199.

Michaelidou, N., and Christodoulides, G. (2011). Antecedents of attitude and intention towards counterfeit symbolic and experiential products. Journal of Marketing Management, 27, 976-991.

Mieres, C., Martin, A., and Gutierrez, J. (2006). Antecedents of the differences in perceived risk between store brands and national brands. European Journal of Marketing, 40, 61-82.

Molina-Castillo F., Lopez-Nicolas C., and Soto-Acosta P. (2012). Interaction effects of media and message on perceived complexity, risk and trust of innovative products. European Management Journal, 30, 577-587.

Murray, K., and Schlacter, J. (1990). The impact of services versus goods on consumers' assessment of perceived risk and variability. Journal of the Academy of Marketing Science, 18, 51-65.

Na, Woonbong, Son, Youngseok, and Marshall, Roger. (2007). Why buy second best? The behavioral dynamics of market leadership. Journal of Product and Brand Management, 16, 16-22.

Parasuraman, A., Zeithaml, V., and Berry, L. (1985). A conceptual model of service quality and its implications for future research. Journal of Marketing, 49, 41-50.

Park, Sun-A. (2008). Consumer health crisis management: Apple's crisis responsibility for iPod-related hearing loss. Public Relations Review, 34, 396-398.

Park, J., Stoel, L. (2005). Effect of brand familiarity, experience and information on online apparel purchase. International Journal of Retail and Distribution Management, 33, 148-160. 
Perrin-Martinenq, D. (2004). The role of brand detachment on the dissolution of the relationship between the consumer and the brand. Journal of Marketing Management, 20, 1001-1023.

Petruzzellis L., Salvatore R., and Vito T. (2011). Branding relationships in financial services: paradigm shift in Mediterranean countries. Journal of Brand Management, $18,312-328$.

Pinhey, T., and Brown, M. (2005). Asian-Pacific islander adolescent sexual orientation and defensive aggression. Social Science Quarterly, 86, 898-911.

Rao, A., and Monroe, K. (1988). The moderating effect on prior knowledge on cue utilizations in product evaluations. Journal of Consumer Research, 15, 253-264.

Richardson, P., Dick, A., and Jain, A. (1994). Extrinsic and intrinsic cue effects on perceptions of store brand quality. Journal of Marketing, 58, 28-36.

Robinson, W., and Fornell, C. (1985). Sources of market pioneer advantage in consumer goods industries. Journal of Marketing Research, 22, 305-317.

Roehl, W., and Fesenmaier, D. (1992). Risk perceptions and pleasure travel: an exploratory analysis. Journal of Travel Research, 30,17-26

Roselius, T. (1971). Consumer rankings of risk reduction methods. Journal of Marketing, $35,56-61$.

Rubinstein, H. (1996). "Brand first" management. Journal of Marketing Management, $12,269-280$.

Scherer, F. (1985). Editorial: post-patent barriers to entry in the pharmaceutical industry. Journal of Health Economics, 4, 83-87.

Simcock, P., Sudbury, L., and Wright, G. (2006). Age, perceived risk and satisfaction in consumer decision making: a review and extension. Journal of Marketing Management, 22, 355-377.

Sinapuelas, Clark S., and Robinson, William T. (2012). Do me-too brands price lower than the feature pioneer? Journal of Product \& Brand Management, 21, 350-358.

Sloan, Paul. (2012). Apple by the numbers: 84M iPads, 400M iOS devices, 350M iPods sold. CNet. http://www.news.cnet.com.

Snoj, B., Korda, A., and Mumel, D. (2004). The Relationships among Perceived Quality, Risk and Product Value. Journal of Product and Brand Management, 13, 156-167.

Sweeney, J., Soutar, G., and Johnson, W. (1999). The role of perceived risk in the quality-value relationship: A study in a retail environment. Journal of Retailing, 75, 77-105. 
Tafarodi, R., and Swann, W. (1996). Individualism-collectivism and global self-esteem. Journal of Cross-Cultural Psychology, 27, 651-672.

Travlos, D. (2012). The iPad will mirror the iPod's market dominance. Here's why and why it matters. Forbes.

Verma, B., and Sharma, K. (1990). Academic achievements as a function of risk taking behavior and gender. Psycho-Lingua, 20,11-16.

Vieceli, J., and Shaw, R. (2010). Brand salience for fast-moving consumer goods: an empirically based model. Journal of Marketing Management, 26, 1218-1238.

Wang, F., Zhang, H., Zang, H. and Ouyang, M. 2005, "Purchasing pirated software: an initial examination of Chinese consumers", Journal of Consumer Marketing, Vol. 22, Iss. 6, pp. $340-351$.

Wolburg, J.M., and Pokrywezynski, James. (2001). A psychographic analysis of Generation Y college students. Journal of Advertising Research, 41, 33-53. 


\section{Table 1: Rotated component matrix for the pioneer brand}

\begin{tabular}{lc}
\hline & $\mathbf{1}$ \\
\hline Factor 1: Perceived social/physical risk & $\mathbf{2}$ \\
May be dangerous for me or some of my family. & 0.88 \\
May make others look down upon me. & 0.84 \\
May negatively affect what others think of me. & 0.84 \\
Would damage my health. & 0.83 \\
Would not be safe for me or my family. & 0.82 \\
I think an Apple iPod may cause me some physical harm. & 0.72 \\
The demands on my schedule are such that purchasing an Apple iPod could create more pressures on me. & 0.61 \\
Factor 2: Brand familiarity & 0.84 \\
I know the MP3 players well. & 0.83 \\
I am very familiar with MP3 players. & 0.83 \\
I know the different available MP3 player brands well. & 0.79 \\
I know the available MP3 player brands well. & 0.79 \\
I am well informed about MP3 players. & 0.75 \\
Compared with most MP3 player buyers, I consider myself a good buyer. & 0.65 \\
I have plenty of experience using MP3 players other than the Apple iPod. & 0.63 \\
When deciding on a MP3 player brand, I feel confident of my choice. & 0.56 \\
When I choose a MP3 player brand, I do not usually doubt my choice. &
\end{tabular}

\section{Factor 3: Perceived psychological risk}

Gives me a feeling of unwanted anxiety.

Causes me to be concerned for how really reliable that product will be.

Causes me to experience unnecessary tension.

As I consider purchasing an Apple iPod soon, I worry about whether it will really 'perform' as it is

\section{Factor 4: Perceived financial/performance risk}

\section{I would not get my money's worth.}

The financial investment I would make would not be wise.

\section{Factor 5: Extrinsic attributes}

If you want quality, you have to pay for it.

The better-known the MP3 player's brand name, the better the quality.

A cheap MP3 player makes me suspicious of the result.

The absence of a well-known MP3 player brand name makes me suspicious.

\section{Factor 6: Perceived time risk}

An inefficient use of my time.

Important time losses.

Important financial losses.

Factor 7: Perceived equivalent quality

The Apple iPod brand and the other MP3 player brands are practically the same quality.

There is not much difference in terms of quality between the Apple iPod brand and the other brands.

I do not think other MP3 player brands are of lower quality than the Apple iPod brand.

KMO score $=0.88$; Bartlett's test of Sphericity $=0.001$

\section{Eigen value}

Variance extracted

Coefficient alpha

\begin{tabular}{ccccccc}
8.49 & 5.23 & 2.46 & 2.29 & 1.33 & 1.26 & 1.19 \\
24.98 & 15.37 & 7.23 & 6.72 & 3.90 & 3.70 & 3.50 \\
0.92 & 0.90 & 0.82 & 0.85 & 0.71 & 0.81 & 0.61 \\
\hline
\end{tabular}




\section{Table 2: Rotated component matrix for the me-too brands}

1

2

3

4

5

6

Factor 1: Brand familiarity

I know the different available MP3 player brands well.

0.85

I am very familiar with MP3 players.

0.84

0.83

0.80

0.77

0.75

0.72

0.68

0.57

When deciding on a MP3 player brand, I feel confident of my choice.

Factor 2: Perceived social/physical risk

Would damage my health.

May be dangerous for me or some of my family.

Would not be safe for me or my family.

May negatively affect what others think of me.

I think another brand of MP3 player may cause me some physical harm.

May make others look down upon me.

Factor 3: Perceived financial/performance risk

I would not get my money's worth.

0.87

0.84

0.69

Causes me to be concerned for how really reliable that product will be.

Factor 4: Perceived psychological risk

Causes me to experience unnecessary tension.

0.79

0.76

0.75

Makes me feel psychologically uncomfortable.

Factor 5: Extrinsic attributes

The better-known the MP3 player's brand name, the better the quality.

0.77

0.75

0.70

0.63

The absence of a well-known MP3 player brand name makes me suspicious.

Factor 6: Perceived time risk

An inefficient use of time.

0.77

0.75

0.64

Important financial losses.

Factor 7: Perceived equivalent quality

The Apple iPod brand and the other MP3 player brands are practically the same quality.

I do not think other MP3 player brands are of lower quality than the Apple iPod brand.

KMO score $=0.88$; Bartlett's test of Sphericity $=0.001$

Eigen value

$\begin{array}{lll}7.46 & 5.56 & 2.80\end{array}$

2.01

1.43

1.12

1.09

Variance extracted

$\begin{array}{lll}24.05 & 17.92 & 9.02\end{array}$

6.48

4.60

3.61

3.51

Coefficient alpha

$0.93 \quad 0.78$

0.92

$\begin{array}{lll}0.71 & 0.83 & 0.61\end{array}$ 
Table 3: Descriptive statistics for the dimensions of risk associated with pioneer and me-too brands

\begin{tabular}{lcc}
\hline & $\begin{array}{c}\text { Apple iPod } \\
\text { (pioneer brand) }\end{array}$ & $\begin{array}{c}\text { Other brands of MP3 } \\
\text { players } \\
\text { (me-too brands) }\end{array}$ \\
\hline Perceived social/physical risk & $2.11^{\mathrm{a}}$ & $2.40^{\mathrm{b}}$ \\
Perceived financial/performance risk & $(1.20)$ & $(1.41)$ \\
Perceived time risk & $3.41^{\mathrm{a}}$ & $4.05^{\mathrm{b}}$ \\
Perceived psychological risk & $(1.45)$ & $(1.40)$ \\
& $3.23^{\mathrm{a}}$ & $2.98^{\mathrm{b}}$ \\
\hline Sample size & $(1.43)$ & $(1.35)$ \\
\hline
\end{tabular}

Note: Standard deviations are shown in parentheses. Means denoted by a different subscript letter are significantly different from one another $(p \leq 0.05)$ using independent groups $t$-tests 
Figure 1: Measurement model for the pioneer brand

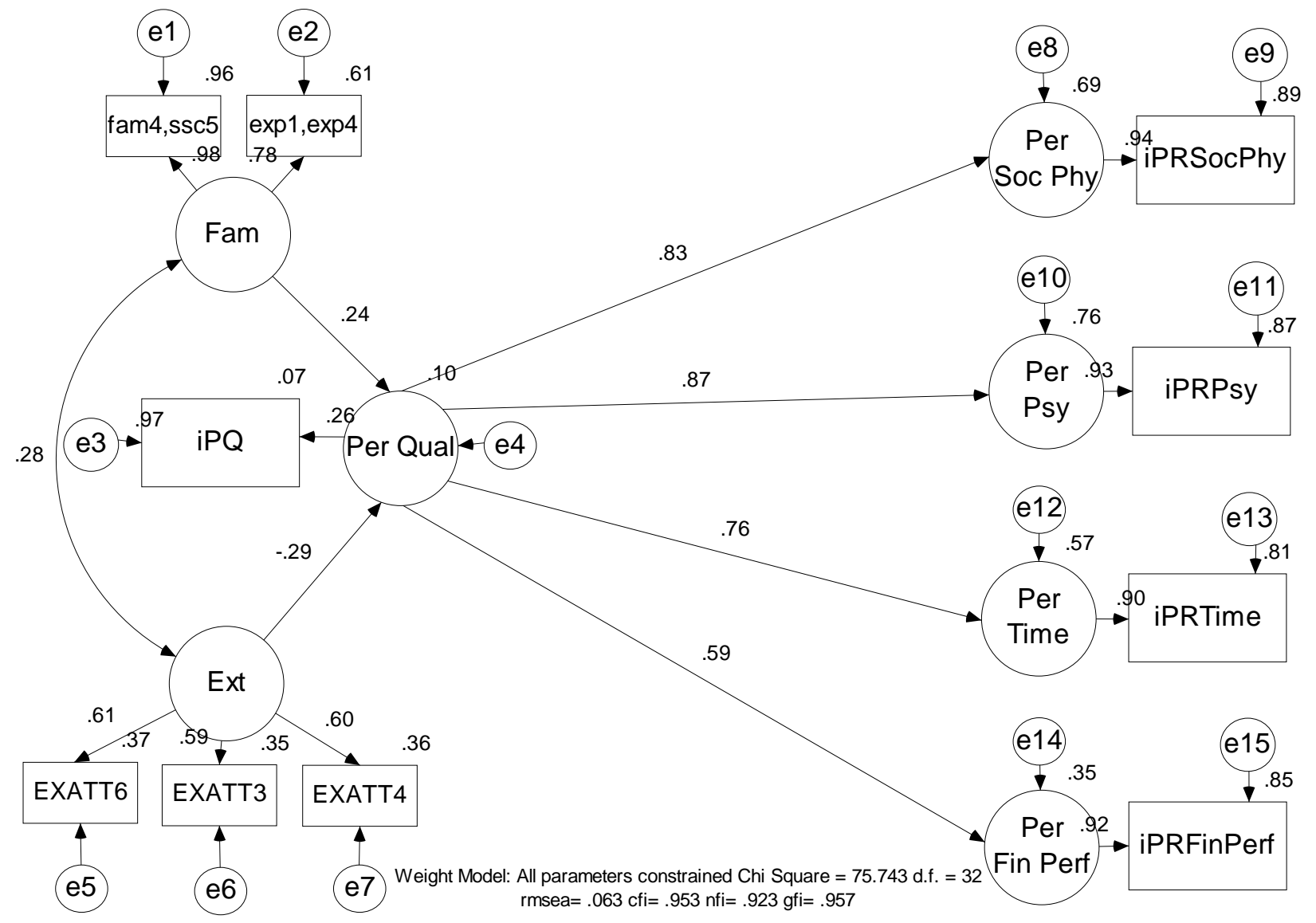


Figure 2: Measurement model for the me-too brands

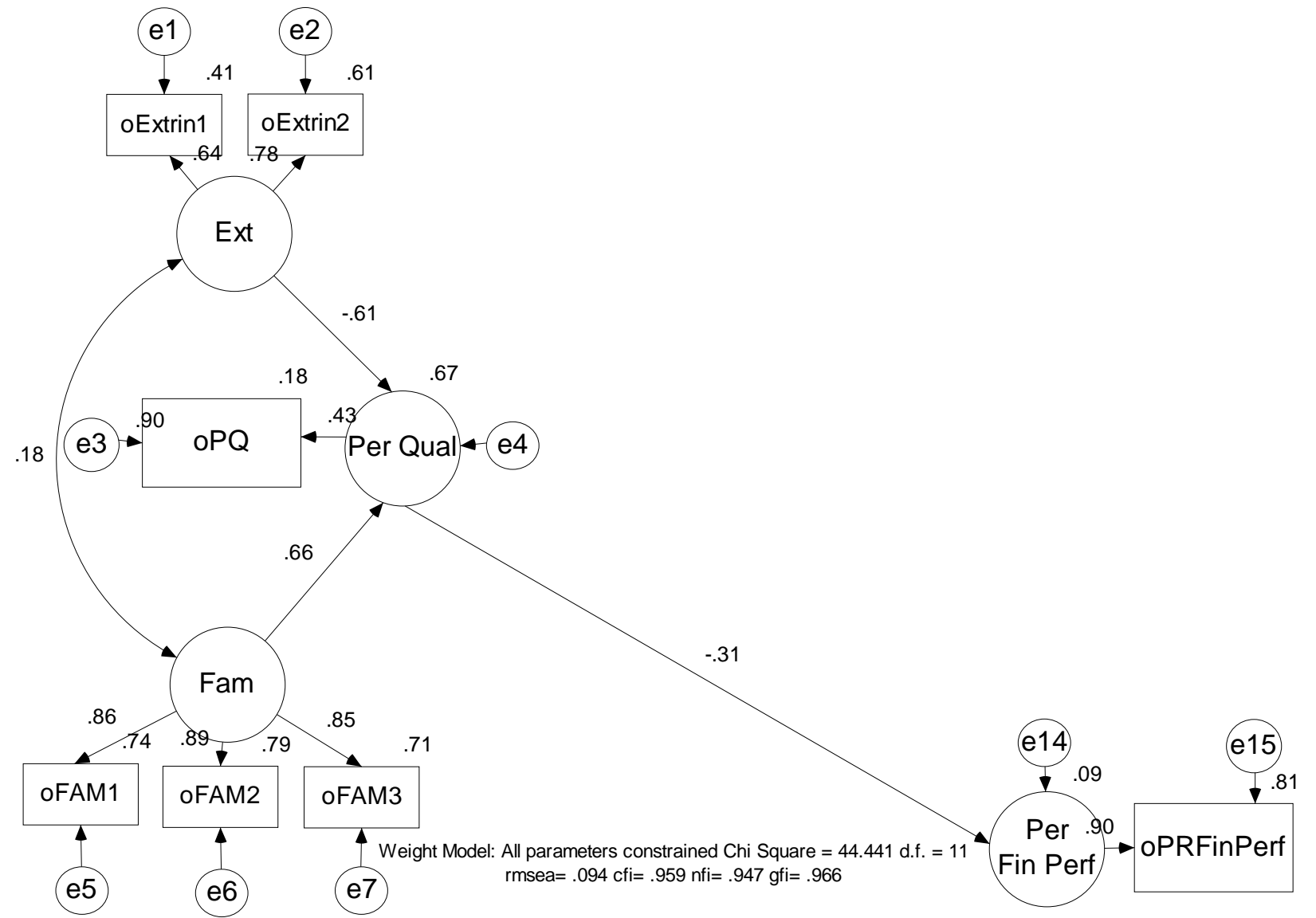


Appendix 1: Constructs means, standardized deviations and correlations

\begin{tabular}{|c|c|c|c|c|c|c|c|c|}
\hline & Items & M & $\mathrm{SD}$ & $\begin{array}{l}\text { Construct } \\
\text { Reliability }\end{array}$ & $\begin{array}{l}\text { AVE } \\
\text { Score }\end{array}$ & $\mathrm{BF}$ & EA & PEQ \\
\hline \multicolumn{9}{|l|}{ Apple iPod (pioneer brand) } \\
\hline Brand familiarity $(\mathrm{BF})$ & 4 & 4.12 & 1.28 & 0.85 & 0.60 & 1.00 & & \\
\hline Extrinsic attributes (EA) & 3 & 4.80 & 1.17 & 0.63 & 0.36 & 0.18 & 1.00 & \\
\hline Perceived equivalent quality (PEQ) & 3 & 3.83 & 1.12 & 0.61 & 0.34 & 0.20 & -0.14 & 1.00 \\
\hline Perceived social/physical risk (PSP) & 4 & 2.11 & 1.20 & 0.89 & 0.68 & 0.17 & -0.15 & 0.16 \\
\hline Perceived financial/performance risk (PFP) & 3 & 3.41 & 1.45 & 0.85 & 0.65 & 0.06 & -0.14 & 0.23 \\
\hline Perceived time risk (PT) & 3 & 3.23 & 1.43 & 0.81 & 0.59 & 0.07 & -0.12 & 0.23 \\
\hline Perceived psychological risk (PP) & 3 & 2.56 & 1.30 & 0.88 & 0.70 & 0.14 & -0.12 & 0.16 \\
\hline \multicolumn{9}{|l|}{ Other brands of MP3 players (me-too brands) } \\
\hline Brand familiarity $(\mathrm{BF})$ & 7 & 4.04 & 1.29 & 0.91 & 0.58 & 1.00 & & \\
\hline Extrinsic attributes (EA) & 4 & 4.70 & 1.10 & 0.72 & 0.39 & 0.14 & 1.00 & \\
\hline Perceived equivalent quality (PEQ) & 3 & 3.83 & 1.12 & 0.61 & 0.34 & 0.26 & -0.15 & 1.00 \\
\hline Perceived social/physical risk (PSP) & 4 & 2.40 & 1.41 & 0.92 & 0.74 & 0.11 & -0.06 & -0.04 \\
\hline Perceived financial/performance risk (PFP) & 3 & 4.05 & 1.40 & 0.81 & 0.58 & -0.11 & 0.14 & -0.12 \\
\hline Perceived time risk $(\mathrm{PT})$ & 3 & 2.98 & 1.35 & 0.85 & 0.66 & 0.02 & -0.01 & 0.04 \\
\hline Perceived psychological risk (PP) & 3 & 2.95 & 1.48 & 0.92 & 0.78 & 0.10 & -0.01 & 0.01 \\
\hline
\end{tabular}

